found excepting inside the shells of species of Helix, the animal of which it had previously devoured. R. MCLACHLAN Lewisham, June 27

Your conespondent, R. S. Newall, is upon the wrong tack, I think. His glow'worm was probably eating the snail, and not vice versố.

In Kirby and Spence's "Entomology" I read: "Snails give sustenance to Di:zats favescens, a beetle, and its singular apterous female in the larva state, as well as to the larvas of glow" worms." Is it not probable that the same food suits the imago state of the insect?

I have often found glow-worms in snail sheils, and have al ways considered slugs and snails to be the natural food of the Lamipyris noctilace.

Bishopsteignton, Devon

R. GREENWOOD PENNY

\section{Frogs and Glow-flies}

Mr. Newall may be, perhaps, interested with the following extract frow Darwin's "Botanic Garden," Canto iv. p. I49, note :-

"In Jamaica, in some seasons of the year, the fire-flies are seen in the evenings in great abundance. When they settle on the ground, the bull-frog greedily devours them; which seems to have given origin to a curious, though cruel method of destroying these animals; if red-hot pieces of charcoal be thrown towards thein in the dusk of the evening, they leap at them, and, hastily swallowing them, are burnt to death."

I was toid a few days ago of a cat which used to search for and eat glow-worms. It was suggested that she took thein for lights. GEORGE HENSLOW

\section{Intellect in Brutes}

THE following instance of sagacity in a cat has just been re. lated to me by a friend who knew both the cat and its owner well. The Iatier, who lived at Ragusa Vecchia, in Dalmatia, was too poor to be able to provide fucd for the cat; the animal was therefore obliged to cater for himself, and was well linown as a thief in the neighbourhood. One day one of the children was being sent off to school without any breakfast; the cat, hearing him sobbing for hunger, immediately went off, and returned with a piece of breat he had stolen from a baker hard by, and brought it to the child. The same thing happened another day, and he came back, dragsing along a piece of meat bigger than himself. On crossing the threshold a bit of bone caught in a bole, so puss miawed till some one came to his help. This same cat, who was constantly catching birds on the roof, slept. with some pet birds in a cage without attempting to touch them.

Ragusa, Austria, June is

MARgaret EvaNS

I SEND you the following instance of intelligence in dogs :Last summer, when on a visit at the château of my son-in-law, M. Richart Waddington, Deputé, near Rouen, I had taken a walk in the grounds, accompanied by some of the family, and two favourte $\log s$, named respectively Minos and Rhadaman. thus, followed the party, as usual, throughout the stroll. When nearing the house, on the return, my young grand-daughter rematke that Minos had lost his collar. The party came to a 32alk, clebating whether it was worth while to go back on a search. ing exvedition, for the pleasure gronds are somewhat exten. sive, and the cogs had been rambling away from the paths among long yrass. Both Minos and Rhadamanthus evidently seemed 10 listen to tine ciebate. It was clecided to make the searcls at a ventme, anc, without saying a word to the dogs, the party commenced to retrace their steps. As a rule, these two dozs are inseparable; wherever the one goes, the other goes, and invariably the two follow any members of the family when strolling about the place. At this juncture, however, Rhadamantbus, not having lost a collar, and having no special interest in the proposed search, went on her solitary way home to the stables ; but Minos kept with the party, walking on the gravel path-and this for some distance-when suddenly he took to the meadow, commenced ruming, and presently he was observed to stop and remain fixed with his head pointed downwards, partly buried in the tall grass. Naturally he was followed. The point of his nose was in contact with the collar! Could any child of man, under similar circumstances, have displayed more thoughtful sagacity than did each of the above dogs on the above occasion? The one thought she was not wanted, and having had enough play, wisely went home, whilst the other, thinking that his presence was requisite, wisely returned with the searching party.

When in Bute, some years ago, I heard from a gentleman, perfectly trustworthy, that a large Newfoundland dog, belonging to a friend of his, was observed one night by its ownei lying concealed under his bed-a strange circumstance, because the dog was forbidden to enter the house at night. The owner, being struck by this singular occurrence, resolved not to disturb the creature, and, getting into bed, kept himself awake to watch events. It was not long before a sound was heard in the pas. sage, a faint light was seen through the key-hole, the door opened, and instantly the dog flew from under the bed, and, springing forward, brought a man to the ground, the gentleman's own servant, who, accompanied by another fellow, was there for the purpose of robbery.

Vicarage, Monkwearmouth

Chas, POPHAM Miles

HAviNG read Mr. Peach's letter on "Intellect in Brutes," as shown by the sagacity he witnessed in his dog, I have been asked to send a similar anecdote, which I have often told to friends. Many years ago my husband had his portrait taken by T. Phillips, sen., R.A., and subsequently went to India, leaving the portrait in London to be finished and framed. When it was sent home about two years after it was taken, it was placed on the floor against the sofa, preparatory to being hung on the wall. We had then a very handsome large black and tan setter, which was a great pet in the house. As soon as the dog came into the room he recognised his master, though he had not seen him for two years, and went up to the picture and licked the face. When this anecdote was told to Phillips, he said it was the highest compliment that had ever been paid to him.

SOME years ago a fine atts exhibition was held at Derby. A portrait of a Derby artist, Wright, was thus sigualised: "The artist's pet dog distinguished this, from a lot of pictures upon the floor of the studio, by licling the face of the portrait."

Derby

HENRY CLARK

\section{Butterfly Swarms}

Wrot reference to the swarms of butterflies referred to by $M$. Forel, in NATURE, vol, xx. p. 197, it may be interesting to mention that Vanessa cardui is this year very common in the south of England. This butterfy is known to all English lepicopterists to be "periodical"-in some seasons it occur's in great numbers, in others-perhaps for several years in succession -not one specimen is to be seen.

Last season (I878) I saw no specimens, nor dià $I$ bear of any about here. It seems, therefore-in such a baci season for insects as the present-impossible to consider the abundance of the species in England to be the result of "local fecundity." Whence, therefore, come these specimens? and is the periodical abundance of the species in Britain due to local causes or migration?

4, East Street, Lewes, July $x$

J. H. A. JENNER

\section{THE KILBURN SHOW}

$T T$ is difficult to estinate the disadvantages with which the Agricultural Exhibition at Kilburn has had to contend. So large a show must always be somewhat unwieldy, however skilfully planned, but the melancholy wet season has enormously increased the difficulties of arrangement, and we may add that tairly to study the implements and miscellaneous exhibits was quite impossible up to the time of otir going to press. A few jottings set down at random concerning such instruments, operations, and specimens as drew our attention while in the yard on Monday must suffice on the present occasion. Visitors were supposed to view the exhibits from the avenues between the long rows of sheds; but these avenues, once grass, were transformed into roads of mud, in every condition of matter between the solid and liquid states. There were no paths across the sheds, and as most of the implements and other exhibits were not so arranged as to be approachable on more than one side, the difficulty of examining objects of interest was frequently insurmountable. 